Jurnal Hukum Mimbar Justitia

Fakultas Hukum Universitas Suryakancana

Vol. 3 No. 2 - Desember 2017 p. 216-233

ISSN: 2477-5681 (Cetak), ISSN: 2580-0906 (Online)

Open Access at: https://jurnal.unsur.ac.id/jmj

\title{
PENEGAKAN HUKUM LEGALISTIK DALAM PERSPEKTIF SOSIOLOGIS
}

\author{
Cecep Wiharma \\ Universitas Islam Bandung \\ E-mail: cecepwiharma@gmail.com
}

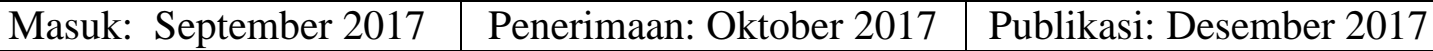

\begin{abstract}
ABSTRAK
Faktor kesadaran hukum masyarakat itu sangat memegang peranan penting dalam upaya penegakan hukum itu sendiri, karena persfektif inilah yang perlu ditata agar supremasi hukum di negeri ini dapat berjalan. Relevansi penegakan hukum dalam perspektif penegakan keadilan sebagai bagian dari kesadaran hukum masyarakat, merupakan upaya alternatif atas ketidakpercayaan terhadap hukum positif dan aparat penegak hukumnya yang merupakan mainstream dari pandangan legalistik. ketika berbicara hukum dalam persfektif keadilan dalam wilayah etika atau moralitas dan tidak membahas masalah-masalah hukum dalam arti sempit. Bagaimana hukum positif dibuat, dan apakah hukum positif yang dibuat telah merepresentasikan dari unsur rasa keadilan masyarakat, serta mentalitas aparatur hukum yang menegakkan hukumnya? Budaya hukum masyarakat tergantung kepada budaya hukum anggota-anggotanya yang dipengaruhi oleh latar belakang pendidikannya, lingkungan, budaya, posisi atau kedudukan, bahkan kepentingan-kepentingan.
\end{abstract}

Kata Kunci: Penegakan Hukum, Kesadaran Hukum, dan Kedailan

\begin{abstract}
The law society's awareness of the factors that strongly holds an important role in the efforts of the law enforcement itself, because it is this persfektif that need to be arranged so that the rule of law in this country can run. The relevance of the rule of law in the perspective of the rule of Justice as part of the legal consciousness of the public, is an alternative effort over mistrust against law enforcement officials of the ruling is positive and which is the mainstream of the view legalistic. When talking about the law in persfektif justice in the area of ethics or morality and does not discuss the legal issues in a sense narrow. How positive law is made, and whether it has made positive law represents the community's sense of fairness, as well as the legal apparatus that this mentality of enforcing the law? The culture of the law society legal culture depends on its members which is influenced by the background of his education, the environment, culture, position, even the interests.
\end{abstract}

Keywords: $\quad$ Law enforcement, Legal Awareness, and Justice 


\section{PENDAHULUAN}

Berbicara mengenai upaya penegakan hukum, sama artinya dengan sebuah upaya untuk memahami hukum. Kendati untuk memahami hukum secara benar, kita harus mempelajari seluruh peraturan perundang-undangan yang ada maupun bagaiman upaya penegakan hukum itu sendiri di masyarakat. Seringkali kita memahami hukum dengan hanya melihat bagaimana upaya penegakan hukum yang dilakukan oleh aparat penegak hukum dan dengan hanya melihat kondisi hukum yang terjadi saat ini. Henny mengatakan bahwa then one as the deciding factor in holding power is the norm or law. ${ }^{1}$ Sehingga selalu saja yang disalahkan adalah hukum itu sendiri atau aparat penegak hukumnya yang "tidak becus" menegakkan hukum. Pandangan ini muncul karena kita melihat dan memahami hukum hanya dari dua sisi tersebut, dan hal ini seringkali menjadikan kita cenderung apatis dan pesimis dengan hukum yang berlaku sekarang. Namun bagaimana dengan

1 Henny Nuraeny \& Tanti Kirana Utami, The Victim Handling Model of Human Trafficking through Economic Independence, Vol. 16 No. 2 Mei 2016, FH-UNSOED, HIm. 121. DOI. 10.20884/1.jdh.2016.16.2.507. masyarakatnya sendiri, apakah budaya hukumnya juga sudah tinggi?

Padahal salah satu unsur yang cukup penting dalam penegakan hukum adalah unsur manusianya sendiri, yaitu aspek kesadaran hukum. Karena ketika kita berbicara unsur manusia dari aspek kesadaran hukum masyarakatnya, maka mencoba memahami dan menyoroti segi manusia individunya yang membentuk budaya hukumnya. Di sinilah harus dibicarakan soal mental, akhlak, moral, etika, sebab semua itulah substansi dari seorang individu manusia, "the moral of the man”. Budaya hukum masyarakat yang tinggi, adalah masyarakat yang tidak cenderung melanggar hukum walaupun tidak ada aparat hukum yang melihatnya. Masyarakat yang tidak memanfaatkan hukum untuk mencapai tujuan bagi kepentingannya sendiri atau kelompoknya. Apalagi masyarakat yang cenderung untuk menghindari atau menyalahgunakan hukum dengan sengaja untuk tujuan-tujuan tertentu yang pada akhirnya bersifat tidak adil bagi masyarakat lainnya. Sehingga tegaknya hukum di tengah masyarakat memerlukan tegaknya keadilan. Melukai rasa keadilan terhadap sebagian masyarakat dapat berakibat 
rusaknya tatanan dan kestabilan bagi masyarakat keseluruhan karena rasa keadilan adalah unsur fitrah sejak lahir bagi seorang manusia.

Disinilah faktor kesadaran hukum masyarakat itu sangat memegang peranan penting dalam upaya penegakan hukum itu sendiri, karena persfektif inilah yang perlu ditata agar supremasi hukum di negeri ini dapat berjalan. Relevansi penegakan hukum dalam perspektif penegakan keadilan sebagai bagian dari kesadaran hukum masyarakat, merupakan upaya alternatif atas ketidakpercayaan kita terhadap hukum positif dan aparat penegak hukumnya yang merupakan mainstream dari pandangan legalistik. Ketika berbicara hukum dalam persfektif keadilan, berada dalam wilayah etika atau moralitas dan tidak membahas masalah-masalah hukum dalam arti sempit. Bagaimana hukum positif dibuat, dan apakah hukum positif yang dibuat telah merepresentasikan dari unsur rasa keadilan masyarakat, serta mentalitas aparatur hukum yang menegakkan hukumnya?

Mengingat bahwa kemajemukan budaya itu telah ada di bumi Nusantara bahkan sebelum Indonesia sebagai sebuah nation state modern lahir.
Kedengarannya cukup masuk akal apabila kadang-kadang ada klaim bahwa multikulturalisme sudah merupakan warisan luhur budaya bangsa sejak dahulu kala, multikulturalisme adalah sebuah kualitas dan bukan entitas, sebuah semangat dan bukan sederetan angkaangka. Konteks Indonesia khususnya, multikulturalisme bukanlah sebuah warisan luhur nenek moyang yang harus dilestarikan dan dipelihara melainkan sesuatu yang masih harus diperjuangkan, dibangun dan diwujudkan ke depan. ${ }^{2}$

Pengetahuan hukum pada umumnya memusatkan perhatian pada atura-aturan yang dianggap oleh Pemerintah dan masyarakat sebagai aturan-aturan yang sah berlaku dan oleh sebab itu harus ditaati, dan pengetahuan sosiologi sebagai keseluruhan yang memusatkan perhatian pada tindakantindakan yang dalam kenyataan diwujudkan oleh anggota dalam hubungan mereka satu sama lain, maka untuk pengembangan hukum dan

2 Manneke Budiman, "Jatidiri Budaya Dalam Masyarakat Multikultural", Makalah Seminar Pendidikan Multikultural dan Revitalisasi Hukum Adat dalam Perspektif Budaya, Departemen Kebudayaan dan Pariwisata, Bogor 18-20 Desember 2003. 
pengetahuan hukum dalam kehidupan masyarakat agar tidak terpisah satu sama lain harus memperhatikan hukum dan kenyataan-kenyataan masyarakat.

Penegakan hukum di Indonesia agar memenuhi aspek moral dan keadilan hendaklah dikaitkan dengan 3 (tiga) faktor dari sistem hukum sebagaimana yang diutarakan oleh Lawrence M.Friedman tentang tiga unsur sistem hukum (three elements of legal system) yaitu :

1. Struktur (Structure)

2. Substansi (Substance)

3. Kultur/Budaya hukum (Legal Culture). ${ }^{3}$

Agar hukum di Indonesia dapat ditegakkan dengan adil maka menurut Barda Nawawi, reformasi hukum tidak hanya berarti pembaharuan undangundang atau substansi hukum (legal substance reform) tetapi juga pembaharuan struktur hukum (legal structure reform) dan pembaharuan budaya hukum (legal substance reform) yang termasuk didalamnya juga etika hukum dan ilmu/pendidikan hukum. ${ }^{4}$

Kesadaran hukum dapat juga ditingkatkan dengan cara memberi contoh untuk masyarakat melalui peranan para penegak hukum seperti polisi dan hakim, mengingat masyarakat kita masih bersifat paternalistik. Jika semua faktor tersebut di atas dapat dilaksanakan dengan baik, tentunya peraturan hukum akan dapat ditegakkan karena kesadaran hukum masyarakat sudah dibina sedemikian rupa sehingga dapat memperkecil kemungkinan terjadinya penyimpangan tingkah laku yang tidak sesuai dengan hukum.

Berdasarkan uraian di atas, agar pembahasan masalah dapat terarah, maka penulis membatasi ruang lingkup perumusan masalah sebagai berikut mengapa perlu Penegakan hukum legalistik dan rasa keadilan masyarakat? bagaimanakah Kepastian Hukum dan Pembentukan Budaya Hukum atas Dasar Keadilan?

3 Moh. Mahfud MD, "Keniscayaan Reformasi Hukum: Upaya Menjaga Jati Diri Dan Martabat Bangsa", Makalah dalam Konvensi Kampus VI dan Temu Tahunan XII Forum Rektor Indonesia (FRI) di Universitas Tanjungpura Pontianak, 9 Januari 2010.

4 M. Friedman, Lawrence. The Legal System. A Social Science Perspective, (New York: Russel Sage Foundation, 1986), hal.17. 


\section{PEMBAHASAN}

\section{Penegakan hukum legalistik} dan rasa keadilan masyarakat.

\section{Penjelasan Undang-Undang Dasar}

Republik Indonesia Tahun 1945 menyatakan bahwa Indonesia adalah negara yang berdasar atas hukum (Rechtstaat). Tujuan utama negara hukum adalah untuk menyelenggarakan ketertiban. ${ }^{5}$ Hukum merupakan sarana kontrol sosial diwujudkan dalam sanksisanksinya, yang berkolerasi antara penerapan hukum sebagai kebijakan hukum, khususnya hukum pidana. $^{6}$

Hukum sangat berkaitan erat dengan kebudayaan. Hukum sendiri merupakan produk kebudayaan, karena sejatinya produk hukum adalah produk ciptaan manusia. Dalam studi hukum dikenal struktur hukum, substansi hukum, dan budaya hukum. Hukum diciptakan memiliki karakteristik yang berbeda-beda dari satu daerah ke daerah lainnya sesuai dengan kebudayaan

5 Ahmad Hunaeny dan Tanti Kirana Utami, Eksistensi Pekerja Dalam Sistem Hubungan Industrial Di Indonesia Dihubungkan Dengan Pola Integralistik Demokrasi Ekonomi Pancasila, PJIH Volume 3 Nomor 2 Tahun 2016, FH-UNPAD, Bandung, hlm. 407.

6 Aji Mulyana, Perlindungan Hukum Terhadap Perempuan dan Anak Akibat Tindak Pidana Abortus Provokatus Criminalis, Jurnal Wawasan Yuridika, Volume. 1, Nomor. 2, Sepetmber 2017, hlm. 139-154. setempat. Artinya, kebudayaan membentuk hukum. Menurut Satjipto, hukum itu bukanlah skema yang final, tetapi terus bergerak sesuai dengan dinamika dan perkembangan zaman umat manusia. Artinya, hukum akan terus berubah sesuai dengan perkembangan zaman dan dinamika manusia ini terlahir dalam proses kebudayaan yang berbeda.

Hukum yang lahir dari kebudayaan merupakan suatu proses hukum yang lahir dengan cara bottomup (dari bawah keatas), dari akar rumput masyarakat, dari kaidah-kaidah kepercayaan, spiritual, dan kaidah sosial yang ada di masyarakat menjadi suatu hukum yang berlaku. Hukum Adat juga demikian, ada karena budaya di masyarakat yang membangunnya. Bahwa Hukum Adat antara masyarakat Jawa, masyarakat Minang, masyarakat Bugis adalah berbeda. Ini adalah suatu konsep pluralisme hukum (legal pluralism) dimana hukum hadir dalam bentuk kemajemukan kebudayaan. ${ }^{7}$

Perlunya rasa keadilan masyarakat dalam penegakan hukum terlihat dari apa yang diungkapkan

Hubungan Hukum Dengan Struktur Sosial \& Dinamika Sosial", http://zriefmaronie. blogspot.com, diakses tanggal 9 nopember 2017. 
oleh Zudan Arif Fakrullah, bahwa "Penegakan hukum merupakan pusat dari seluruh "aktivitas kehidupan" hukum yang dimulai dari perencanaan hukum, pembentukan hukum, penegakan hukum dan evaluasi hukum. Penegakan hukum pada hakikatnya merupakan interaksi antara berbagai perilaku manusia yang mewakili kepentingan-kepentingan yang berbeda dalam bingkai aturan yang telah disepakati bersama. Oleh karena itu, penegakan hukum tidak dapat sematamata dianggap sebagai proses menerapkan hukum sebagaimana pendapat kaum legalistik. Namun proses penegakan hukum mempunyai dimensi yang lebih luas daripada pendapat tersebut, karena dalam penegakan hukum akan melibatkan dimensi perilaku manusia. Dengan pemahaman tersebut maka kita dapat mengetahui bahwa problem-problem hukum yang akan selalu menonjol adalah problema "law in action" bukan pada "law in the books". 8

Pengadilan yang merupakan representasi utama dari wajah penegakan hukum dituntut untuk tidak

8 Zudan Arif Fakrulloh,. Penegakan Hukum Sebagai Peluang Menciptakan Keadilan, Jurisprudence, Vol. 2, No. 1, Maret 2005: 22 - 34. hanya mampu melahirkan kepastian hukum, melainkan pula keadilan, kemanfaatan sosial dan pemberdayaan sosial melalui putusan-putusan hakimnya. Karena dengan adanya kegagalan lembaga peradilan dalam mewujudkan tujuan hukum diatas telah mendorong meningkatnya ketidakpercayaan masyarakat terhadap pranata hukum dan lembaga-lembaga hukum. $^{9}$

Dalam pikiran para yuris, proses peradilan sering hanya diterjemahkan sebagai suatu proses memeriksa dan mengadili secara penuh dengan berdasarkan hukum positif sematamata. Pandangan yang formal legistis ini mendominasi pemikiran para penegak hukum, sehingga apa yang menjadi bunyi undang-undang, itulah yang akan menjadi hukumnya. Kelemahan utama pandangan ini adalah terjadinya penegakan hukum yang kaku, tidak diskresi dan cenderung mengabaikan rasa keadilan masyarakat karena lebih mengutamakan kepastian hukum. Proses mengadili dalam kenyataannya bukanlah proses yuridis semata. Proses peradilan bukan hanya proses menerapkan pasal-pasal dan

\footnotetext{
9 Ibid,
} 
bunyi undang-undang, melainkan proses yang melibatkan perilakuperilaku masyarakat dan berlangsung dalam struktur sosial tertentu. Penelitian yang telah dilakukan oleh Marc Galanter di Amerika Serikat dapat menunjukkan bahwa suatu putusan hakim ibaratnya hanyalah pengesahan saja dari kesepakatan yang telah dicapai oleh para pihak. Dalam perspektif sosiologis, lembaga pengadilan merupakan lembaga yang multifungsi dan merupakan tempat untuk "record keeping", "site of administrative processing", "ceremonial changes of status", "settlement negotiation", "mediations and arbitration", dan warfare. ${ }^{10}$

Salah satu masalah yang dihadapi bangsa ini adalah tidak adanya kepastian hukum.Belum terciptanya law enforcement di negeri ini terpotret secara nyata dalam lembaga peradilan. Media masa bercerita banyak tentang hal ini, mulai dari mafia peradilan, suap ke hakim, pengacara tidak bermoral sampai hukum yang berpihak pada kalangan tertentu. Yang pada akhirnya perhatian masyarakat terhadap lembagalembaga hukum telah berada pada titik

10 Marc Galanter, Justice in Many Rooms. 1981,. nadir. Hampir setiap saat dapat menemukan berita, informasi, laporan atau ulasan yang berhubungan dengan lembaga-lembaga hukum kita. Salah satu permasalahan yang perlu mendapat perhatian kita semua adalah merosotnya rasa hormat masyarakat terhadap wibawa hukum. ${ }^{11}$ Hal ini selaras dengan pengertian bahwa one of the main factors and actors who play a role in realization of clean government and good governance is bureaucracy. ${ }^{12}$

Ungkapan-ungkapan ini merupakan reaksi dari rasa keadilan masyarakat yang terkoyak karena bekerjanya lembaga-lembaga hukum yang tidak profesional maupun putusan hakim/putusan pengadilan yang sematamata hanya berlandaskan pada aspek yuridis. Berlakunya hukum di tengahtengah masyarakat, mengemban tujuan untuk mewujudkan keadilan, kepastian hukum dan kemanfaatan dan pemberdayaan sosial bagi masyarakatnya.

Untuk menuju pada cita-cita pengadilan sebagai pengayoman

11 Zudan Arif Fakrulloh, , Op.Cit.

12 Tanti Kirana Utami, The Position of Filling Pratama High Leadership in Cianjur Regency Under Good Governance Consept. Jurnal Dinamika Hukum, volume 17 No. 02 Mei 2017, FH-UNSOED, 2017, hlm 141. 
masyarakat, maka pengadilan harus senantiasa mengedepankan empat tujuan hukum di atas dalam setiap putusan yang dibuatnya. Hal ini sejalan dengan apa yang menjadi dasar berpijaknya hukum yaitu "hukum untuk kesejahteraan masyarakat".

Dengan demikian, pada akhirnya tidak hanya dikatakan sebagai Law and Order (Hukum dan Ketertiban) tetapi telah berubah menjadi Law, Order dan Justice (Hukum,

Ketertiban /ketentraman, dan Keadilan). Adanya dimensi keadilan dan ketentraman yang merupakan manifestasi bekerjanya lembaga pengadilan, akan semakin mendekatkan cita-cita pengadilan sebagai pengayom masyarakat. ${ }^{13}$

Hakim atau aparat penegak hukum seringkali "bermain dengan peraturan dan prosedur". Hukum bukan dijalankan demi mencapai kesejahteraan dan keadilan, melainkan demi mencapai keadilan yang diinginkan oleh penegak hukum itu sendiri dan terdakwa di atas dalih hukum tertulis.

Padahal hukum, mengutip pendapat Satjipto Rahardjo bukanlah proyek dokumen kertas, tetapi proyek kultural dan antropologis yang memiliki roh keadilan. Karena itu, membaca dan memahaminya sebagai kalimat-kalimat yang kering, linear, dan masial bisa membawa malapetaka. Logika keadilan tidak segera bisa ditemukan dengan membaca peraturan, tetapi dibutuhkan suatu perenungan dan pemahaman lebih dalam terhadap apa yang tertulis. Sebab, di balik hitam-putihnya peraturan hukum adalah semangat - roh -, yaitu keadilanyang menjadi misi utama hukum, yang disebut sebagai nurani hukum. ${ }^{14}$

Di sinilah bahwasanya dalam menjalankan dan mempraktekkan hukum tidak sama dengan menerapkan huruf-huruf peraturan begitu saja, tetapi berusaha mencari dan menemukan makna sebenarnya dari suatu peraturan tertulis. Sehingga, putusan yang diambil benar-benar merupakan putusan yang bernurani dan obyektif. Sebagaimana kata Paul Schoten, guru besar hukum di Belanda, hukum memang ada dalam undang-undang, tetapi masih harus ditemukan. Sebab, hukum bukanlah buku telepon yang hanya memuat daftar peraturan dan pasal, tetapi sesuatu yang sarat dengan makna dan nilai.

14 Satjipto Rahardjo, 2006, Membedah Hukum Progresif, Jakarta: Kompas, hlm. 41 
Putusan-putusan hukum yang hanya bertolak dari apa yang tertera dalam peraturan tertulis, umumnya menghasilkan putusan yang kering, kurang bernurani dan tidak bernilai moral. Sehingga, hasilnya kerap mengecewakan banyak pihak.

\section{Menurut pendapat Satjipto}

Rahardjo, keadilan pun tidak lagi mirip orang buta yang selalu terantuk pada bebalnya sistem kekuasaan serta bobroknya mental kalangan aparatur negara dan penegak hukum. Artinya, sistem dan perangkat pendukungnya telah lapuk untuk peduli pada nurani apabila membela kepentingan rakyat. Negara dan aparaturnya pun tidak seperti yang dikatakan oleh filsuf Nietzsche, ibarat monster yang paling dingin dari yang terdingin karena beroperasi dengan mencuri harta kekayaan penduduk dengan bermacam alasan. Spirit dan maksud dari hukum progresif adalah sebagai berikut: per- tama, progresivisme; yang dimaksud dalam hukum progresif ini tentu memiliki makna tersendiri. Teori ini lebih dalam sesungguhnya berangkat dari keberanian- nya untuk menilai kesamaan manusia yang memiliki kecenderungan untuk selalu berbuat baik (hanif). Oleh sebab itulah maka titik tolak teori ini berangkat dari manusia dengan seluruh sifat kemanusiaannya yang butuh alat untuk menjabarkannya dalam praktek kehidupan sehari-hari. ${ }^{15}$

Cara berpikir hukum modern yang menggunakan paradikma positivis- tik mengharuskan orang melihat hukum dalam teks-teks mati yang di sahkan oleh lembaga resmi yang bernama negara. Legitimasi tunggal berlakunya hukum dalam perspektif ini adalah kekuasaan negara yang bersifat memaksa dengan seluruh instrumen-instrumen yang menyertainya. Oleh karenanya, hukum ini memiliki potensi besar disalah gunakan oleh penguasa untuk menjadi alat penjaga status quo. Dengan kalimat lain, paradigma hukum ini membuat orang tidak lagi membaca undang- undang untuk dipraktekkan melainkan hanya sekedar mengeja undang-undang semata. Padahal kata kunci dari paradigma hukum progresif adalah kerelaan untuk membebaskan diri dari status quo yang 
memenjarakan manusia dalam ketertindasan. $^{16}$

Hingga kini proses penegakan hukum masih buram. Hal ini terjadi akibat proses panjang sistem politik masa lalu yang menempatkan hukum sebagai subordinasi politik. Sistem peradilan yang tidak independen dan memihak dengan dalih dan banyaknya kepentingan. Reformasi hukum yang dilakukan hingga kini belum menghasilkan keadilan bagi seluruh masyarakat. Keadilan masih dibayangi oleh kepentingan dan unsur kolusi para aparat penegak keadilan dinegeri yang ber-keadilan sosial bagi seluruh rakyat indonesia ini. Sehingga intervensi terhadap hukum masih belum dapat dihindari. Hal ini mempengaruhi mentalitas penegak hukum. Padahal mentalitas yang bermoral adalah kekuatan penegak hukum sebagai dasar dari profesionalismenya. Moral dan keberanian dalam menegakan supremasi hukum masih minim dimiliki oleh penegak hukum di Indonesia. Sehingga banyak kasus-kasus hukum diselesaikan tetapi tidak memuaskan pelbagai pihak atau pun merugikan dilain pihak.

\footnotetext{
16 Satjipto Rahardjo, 2009, Hukum Progresif Sebuah Sintesa Hukum Indonesia, Yogyakarta: Genta Publishing, hlm. 46-48.
}

Timbul pertanyaan apakah keadilan hanya milik 'penguasa' ?

Agar hukum di Indonesia dapat ditegakkan dengan adil maka menurut Barda Nawawi, reformasi hukum tidak hanya berarti pembaharuan undangundang atau substansi hukum (legal substance reform) tetapi juga pembaharuan struktur hukum (legal structure reform) dan pembaharuan budaya hukum (legal substance reform) yang termasuk didalamnya juga etika hukum dan ilmu/pendidikan hukum. ${ }^{17}$

\section{Kepastian Hukum dan Pembentukan Budaya Hukum atas Dasar Keadilan.}

Kaitan antara manusia dan hukum, sebagaimana dikemukakan oleh Mochtar Kusumaatmadja, bahwa tujuan pokok dan pertama dari hukum adalah ketertiban, karena ketertiban merupakan syarat pokok (fundamental) bagi adanya suatu masyarakat manusia yang teratur, disamping tercapainya keadilan yang berbeda-beda isi dan ukurannya, menurut masyarakat dari zamannya. Untuk mencapai ketertiban dalam

\footnotetext{
17 Supriyanta, "Demokratisasi Dalam Penegakan Hukum", Wacana Hukum, Volume.VII, Edisi April 2008, hIm. 93.
} 
masyarakat ini diperlukan adanya kepastian dalam pergaulan antar manusia dalam masyarakat. ${ }^{18}$

\section{Menurut Soejono Soekamto,}

"Penegakan hukum adalah kegiatan menyerasikan hubungan nilai-nilai yang terjabarkan dalam kaidah-kaidah, pandangan-pandangan yang mantap dan mengejawantahkannya dalam sikap, tindak sebagai serangkaian penjabaran nilai tahap akhir untuk menciptakan kedamaian pergaulan hidup."19

Karena itu tegaknya hukum dapat ditandai oleh beberapa faktor yang saling terkait sangat erat yaitu: Pertama, Hukum dan aturannya sendiri, sehingga diperlukan adanya keserasian antara peraturan perundangundangan yang ada. Kedua, fasilitas pelaksanaan hukumnya yang memadai, sebab sering kali hukum sulit ditegakkan bahkan tak tertangani karena fasilitas untuk menegakkannya tidak memadai ataupun tidak tersedia. Ketiga, Kesadaran dan kepastian hukum serta perilaku

18 Otje Salman dan Eddy Damian (ed), "Konsep-konsep Hukum dalam Pembangunan." Kumpulan Karya Tulis Prof. Dr. Mochtar Kusumaatmadja, Bandung: Alumni, 2002, hlm. 3.

19 Soekanto, Soerjono, Faktor-Faktor yang Mempengaruhi Penegakkan Hukum, PT. Raja Grafindo Persada, Jakarta:1983, hal. 3. masyarakat itu sendiri. Keempat, Mental aparat penegak hukum. Dalam hal ini adalah pelaku hukum secara langsung seperti polisi, jaksa, pengacara, hakim, petugas lembaga pemasyarakatan dan sebagainya karena pada dasarnya penegakan hukum sangat tergantung pada mentalitas para aparatur penegak hukumnya.

Dari pendapat diatas, jelas terlihat bahwa penegakan hukum selain ditentukan oleh aturan-aturan hukumnya sendiri, fasilitas, mentalitas aparat penegak hukum, juga sangat tergantung kepada faktor kesadaran dan kepatuhan masyarakat, baik secara personal maupun dalam komunitas sosialnya masing-masing. Pada akhirnya kembali pada unsur manusianya (budaya) juga yang menentukan corak yang sebenarnya; in the last analysis it is the human being that counts. ${ }^{20}$

Sehingga adanya hukum yang baik dan benar tidak otomatis menjamin kehidupan masyarakat yang baik dan benar. Adanya polisi, jaksa, hakim, pengacara sebagai penegak hukum langsung dan formal belumlah menjamin tegaknya hukum dan

20 Natsir, Muhammad, Demokrasi di Bawah Hukum, Media Dakwah, Jakarta: 1987. 
berlakunya rule of law. Adanya parlemen sekalipun dipilih lewat pemilu dengan ongkos besar belum otomatis demokrasi tumbuh.

Sejalan dengan hal ini dalam upaya penegakan hukum, adalah sebagaimana yang diungkapkan oleh Lawrence M. Friedman, dimana hukum harus diartikan sebagai suatu isi hukum (content of law), tata laksana hukum (structure of law) dan budaya hukum (culture of law). Sehingga, penegakan hukum tidak saja dilakukan melalui perundangundangan, namun juga bagaimana memberdayakan aparat dan fasilitas hukum. Juga, yang tak kalah pentingnya adalah bagaimana menciptakan budaya hukum masyarakat yang kondusif untuk penegakan hukum. ${ }^{21}$ Hal ini selaras dengan pendapat Henny bahwa to anticipate it required a legal effort in the prevention and protection. ${ }^{22}$

\section{Dalam Summatheologieae, Thom} as Aquinas mengatakan" Hukum dapat tidak adil ..... karena bertentangan

21 Lawrence M. Friedman, American Law: An Introduction, (New York: W. W. Norton \& Company, 1984), hlm. 5.

22 Henny Nuraeny, Trafficking of Migrant Workers in Indonesia: A Legal Enforcement and Economic Perspective of Prevention and Protection Effort, European Research Studies Journal, volume XX, Issue 4B, 2017, P. 17 dengan kesejahteraan manusia." Hal ini dapat terjadi karena tiga hal;

Pertama, karena penguasa memaksakan hukum yang tidak membawa kesejahteraan umum, tetapi semata-mata hanya keinginan penguasa sendiri;

Kedua, karena pembuat hukum melampaui kewenangan yang dimiliki;

Ketiga, karena hukum dipaksakan kepada masyarakat secara tidak sama, meskipun alasannya demi kesejahteraan umum.

Thomas menyebutnya sebagai tindak kekerasan daripada hukum dan ia mengingatkan seperti yang dikatakan Agustinus, "Suatu hukum yang tidak adil sama sekali bukanlah hukum". ${ }^{23}$

Perspektif ini sangat bertentangan dengan positivisme hukum yang tidak menerima hubungan antara hukum dengan moralitas. Karena menurut pandangan ini terdapat kontradiksi antara moralitas dan kepastian hukum, keadilan hanya dapat diukur dengan hukum yang diberlakukan oleh sebuah otoritas politik sebagai perintah yang berkuasa untuk kelakuan manusia. Moralitas pada dasarnya hanya

23 E. Sumaryono, Etika dan Hukum, Relevansi Teori Hukum Kodrat Thomas Aquinas, Kanisius, Yogyakarta, 2002 hlm. 11. 
merupakan kumpulan asas-asas subjektif tentang kelakuan manusia yang selalu mengalami perubahan. Sehingga menurut pandangan ini, mengakui keberadaan moralitas dalam hukum adalah identik dengan memperkenalkan sebuah asas ketidakpastian hukum.

Sehingga ketika masyarakat sudah pada titik nadir ketidakpercayaan pada struktur hukum dan substansi hukum yang ada di negeri ini, maka penegakan hukum dalam persfektif keadilan menurut hukum kodrat merupakan salah satu alternatif untuk itu. Dalam hal ini Thomas mengklaim bahwa hukum positif yang adil memiliki daya ikat melalui hati nurani subjek hukum. Hukum positif akan disebut adil jika memenuhi persyaratan sebagai berikut:

1. Diperintahkan atau diundangkan demi kebaikan umum;

2. Ditetapkan oleh legislator yang tidak menyalahgunakan kewenangan legislatifnya;dan

3. Hukum positif memberikan beban yang setimpal demi kepentingan kebaikan umum. $^{24}$

Relevansi hukum kodrat untuk situasi dan kondisi tertentu dalam kehidupan sosial manusia, tampak pada perubahan gagasan dasar tentang peranan hukum sebagai ius quia iussum (keberlakuan hukum karena dipaksakan) menjadi ius quia iustum (keberlakuan hukum karena sifat adil), atau perubahan dari pemahaman hukum yang hanya didasarkan atas bentuknya ke pemahaman hukum atas dasar makna isi yang terkandung di dalamnya. Isi hukum ditekankan karena memuat nilai-nilai etika dan moral. Hukum kodrat adalah keterangan tentang sifat rasional dari setiap perbuatan manusia, serta menjadi "jembatan penghubung" antara moralitas dan legalitas. Hukum tidak lain adalah perintah akal budi yang dinyatakan oleh para penguasa untuk mengatur atau menyelenggarakan pemerintahan bagi semua warga negaranya. Sebagai konsekwensinya, mereka yang tidak tertib menaati perintah akal budi dinilai tidak melakukan tindak kebajikan, sebab perilaku kebajikan hanya terdapat di dalam kondisi kebaikan hidup manusia yang tertib.

Dalam analisisnya mengenai hukum

kodrat, Columba

Ryan menyatakan bahwa jika kita membicarakan teori hukum kodrat, kita

24 Ibid, hlm. 20. 
harus memandang hukum kodrat bukan sebagai"yang mendasari" semua hukum yang lain, melainkan justru sebagai inti semua hukum yang lain itu, serta yang menetapkan posibilitasnya. Meskipun demikian, teori hukum kodrat lebih mengarah pada analisis etika atau moralitas. Hukum kodrat pada dasarnya merupakan konsep filosofis yang menjawab persoalan tentang asas yang mendasari keberlakuan hukum. Hukum kodrat adalah dasar ontologis yang terdapat di dalam kodrat manusia, yang menjabarkan terutama posibilitas teori moral dan penegakan hukum. ${ }^{25}$

Dari persfektif inilah, maka hukum sebagai pengatur kehidupan manusia melibatkan peranan setiap orang dan segala sesuatu yang tekait dengan peranan tersebut. Perhubungan hukum tidak hanya meliputi hubungan antara subjek hukum, melainkan juga antara subjek hukum dengan objek hukum. Dasar perhubungan ini adalah asas-asas keadilan dalam hidup bermasyarakat. Sehingga ketika pemahaman masyarakat memandang bahwa hukum positif merupakan representasi atas rasa keadilan masyarakat, maka kesadaran hukum masyarakat akan membentuk budaya hukum yang patuh dan taat pada hukum positif yang berlaku.

Ada yang sangat menarik untuk disimak pada konstitusi negara-negara lain, dimana pengaturan hukum dasarnya berpedoman pada pola pikir hukum yang bermuatan moral. Hal itu menunjukkan budaya hukum (legal culture) yang dianut tidak hanya memandang hukum an sichatau hukum adalah hukum. Pandangan hukum an sich ini dalam konteks pranata hukum yang didasarkan pada teori hukum itu untuk mencari pola pranata hukum yang tepat dan efektif. Jadi maksudnya adalah untuk mencari sintesis antara pola pikir hukum dan pranata hukum lainnya.Seperti pranata hukum yang mengandung moral, agar hukum yang menanggulangi masalah hukum menjadi bermakna. Karena hukum yang bermuatan moral ini sesuai dengan rasa keadilan. Hal ini sejalan dengan salah satu dari tujuan teori keadilan John Rawls. Di dalam "A Theory of Justice" (1971) Rawls mengatakan, untuk mengartikulasikan konsep keadilan adalah dilakukan dengan cara memasukkan pertimbangan moral dalam membuat sesuatu hukum,

${ }^{25}$ Ibid, hal. 26. 
kebijaksanaan, dan tindakan pelaksanaan pencapaian keadilan.

Pandangan hukum yang bermuatan moral ini terasa tidak terbantah dan tidak boleh diabaikan demi tegaknya hukum. Mengapa tidak, oleh karena sudah sejak lama dikenal oleh kerajaan-kerajaan masa lalu, pada masa kekaisaran Roma telah terdapat pepatah "Quid leges sine moribus" ? “Apa artinya undang-undang, kalau tidak disertai moralitas? Berdasarkan pepatah ini atau tidak, Konstitusi Jepang yang diperlakukan pertama kali abad ke-7 oleh Ratu Shotoko telah sarat muatan moral, Pasal 1 Konstitusi ini menyebutkan, "diatas segala kebanggaan apapun, lakukanlah lebih dahulu kewajiban untuk menghindarkan ketidakbanggaan". Walaupun pada permulaan Restorasi Meiji tahun 1868 pada saat Jepang berhubungan dengan Barat, secara efektif telah memakai sistem hukum barat dan hukum Tokugawa secara formal dihapuskan. Namun pengelolaan hukumnya tetap saja berdasarkan nilai-nilai kebiasaannya dengan penekanan pada keindahan dalam kehidupan, memelihara teguh struktur sosialnya, penyerapan nilai-nilai moral manusia dan menghormati kebijaksanaan seseorang yang sudah matang. Pasca Restorasi Meiji, sejak tahun 1895 Jepang telah menjadi negara modern dan hukumnya berjalan dengan baik, suara-suara yang muncul pada jalannya hukum bermakna positif.

Sekarang setelah melalui kekalahan pada Perang Dunia II mereka telah masuk pada tahap negara kesejahteraan. Tentunya tahap negara kesejahteaan ini merupakan jaminan jalannya hukum seperti yang diinginkan masyarakatnya. Wajarlah, oleh karena etika masyarakat Jepang tetap mendorong penegakan hukum dan suara hati (consciences) mereka masih memancarkan moral yang memberi penekanan bahwa masuk ke pengadilan dianggap suatu hal yang memalukan.

Dalam dunia akademisi pandangan hukum yang berkaitan dengan moral ini juga telah lama menjadi pembicaraan. H.L.A. Hart dengan sangat simpatik menyebutkan, "hukum harus mengandung aspek internal yang terdiri dari moral dan ketentuan sosial.",26

Konsep hukum Hart ini telah menyita perhatian para ahli hukum dan mereka berusaha memahaminya,

26 H.L.A Hart, The Concept of Law, (Oxford : The Clarendon Press, 1988. 
bahkan membuat komentar, diantaranya komentar Howard Davies dan David

Holdcroft, yang paling menarik untuk dikaji dalam konsep hukum Hart adalah mengenai moral yang terkandung dalam hukum itu, oleh karena memang setiap hukum harus mempunyai perasaan terhadap suatu perbuatan. Mereka mengatakan, keadaan sekarang ini sangat membutuhkan tuntutan moral dalam memperlakukan hukum. ${ }^{27}$

Filsafat hukum yang memandang keterkaitan hukum dan moral serta komentar tuntutan moral dalam memperlakukan hukum sangat terasa kebenarannya. Karena hukum yang mengandung pertimbangan moral sangat relevan untuk menjawab tuntutan masuknya moral dalam hukum dan kondisi hukum yang memprihatinkan sekarang ini, maka perlu mengangkat topik internalisasi moral dalam hukum ke permukaan.

Artinya ide-ide tentang baik dan buruk dan moralitas penting dipakai untuk menjelaskan tingkah laku manusia, khususnya tingkah laku pejabat publik. Untuk keperluan ini

\begin{tabular}{lllr}
\hline 27 & Howards Davies and & David \\
Holdcroft, Jurisprudence & $:$ Texts & and \\
Commentary, 1991. & &
\end{tabular}

pengamatan harus tertuju pada filsafat hukum yang memandang adanya hubungan yang sangat kuat antara hukum dan moral. Hal ini dapat dimulai dari pendapat Hart yang memandang moral sebagai "nature of a rule", seterusnya menjadi aspek internal dari suatu ketentuan, seperti yang dikatakannya bahwa suatu hukum harus mengandung unsur eksternal dan internal, aspek internalnya adalah moral dan ketentuan sosial, pencegahan dan perlindungan.

Cara internalisasi prinsip-prinsip moral dalam hukum dapat dilakukan pada saat pembuatan hukum. Disini hukum diberikan masukan, seperti ideide baik dan buruk, atau moralitas, dan legitimasi, yaitu upaya untuk menjelaskan tingkah laku manusia, khususnya tingkah laku pejabat publik. Sebagai percobaan dapat dilakukan pada internalisasi dimensi moral pejabat publik dalam pembuatan hukum, agar mempunyai moralitas melaksanakan pemerintahan.

\section{PENUTUP}

1. Budaya hukum masyarakat tergantung kepada budaya hukum anggota-anggotanya yang dipengaruhi oleh latar belakang 
pendidikannya,

lingkungan,

budaya, posisi atau kedudukan,

bahkan kepentingan-kepentingan,

ketika "substansi" hukum positif

sudah baik dan benar, dalam

arti legitimitedan mencerminkan

rasa keadilan masyarakat,

"struktur hukumnya" sudah

memadai, maka terakhir

kedudukan "substansi hukum"

diibaratkan sebagai barang apa

yang diproduksi, dan "struktur

hukum" diibaratkan sebagai

mesin-mesin pengelola barang.

Sedangkan "budaya hukum"

diibaratkan sebagai orang-orang

yang menjalankan mesin dan

berkewajiban untuk

menghidupkan, menjalankan dan

mematikan mesin ini, agar dapat

menentukan baik buruknya hasil

barang yang diproduksi.

2. Penegakan hukum sebagai upaya menegakan keadilan dapat pula menjadi sarana kritik atau koreksi atas hukum positif. Jika aspek keadilan merupakan landasan utama aturan hukum positif dan ukuran kelakuan manusia, maka upaya penegakan hukum dapat dilakukan dalam kerangka untuk mencapai keseimbangan hidup antara manusia, sehingga tercipta keadilan, kedamaian, ketertiban, dan kebaikan umum dalam masyarakat. Dengan perkataan lain, kesadaran hukum masyarakat untuk patuh dan taat pada hukum yang berlaku akan membentuk budaya hukumyang tinggi pula, karena kepercayaan masyarakat pada hukum itu sendiri (substansi) dan aparat hukumnya (struktur).

\section{A. Buku}

E. Sumaryono, Etika dan Hukum, Relevansi Teori Hukum Kodrat Thomas Aquinas, Kanisius, Yogyakarta,2002.

Howards Davies and David Holdcroft, Jurisprudence : Texts and Commentary, 1991.

H.L.A Hart, The Concept of Law, (Oxford : The Clarendon Press, 1988).

Howards Davies and David Holdcroft, Jurisprudence : Texts and Commentary, (1991).

M. Friedman, Lawrence. The Legal System. A Social Science Perspective, (New York: Russel Sage Foundation.

Marc Galanter, Justice in Many Rooms. 19811986. W. Norton \& Company, 1984. 
Otje Salman dan Eddy Damian (ed), "Konsep-konsep Hukum dalam Pembangunan." Kumpulan Karya Tulis Prof. Dr. Mochtar Kusumaatmadja, Bandung: Alumni, 2002.

Soekanto, Soerjono, Faktor-Faktor yang Mempengaruhi Penegakkan Hukum,PT. Raja Grafindo Persada, Jakarta:1983.

Satjipto Rahardjo, Hukum Progresif Sebuah Sintesa Hukum Indonesia, Yogyakarta: Genta Publishing, 2009.

\section{B. Jurnal dan Internet}

Aji Mulyana, Perlindungan Hukum Terhadap Perempuan dan Anak Akibat Tindak Pidana Abortus Provokatus Criminalis, Jurnal Wawasan Yuridika, Volume. 1, Nomor. 2, Sepetmber 2017.

Ahmad Hunaeny dan Tanti Kirana Utami, Eksistensi Pekerja Dalam Sistem Hubungan Industrial Di Indonesia Dihubungkan Dengan Pola Integralistik Demokrasi Ekonomi Pancasila, PJIH Volume 3 Nomor 2 Tahun 2016, FHUNPAD, Bandung.

Henny Nuraeny \& Tanti Kirana Utami, The Victim Handling Model of Human Trafficking through Economic Independence, Vol. 16 No. 2 Mei 2016, FH-UNSOED, DOI.

10.20884/1.jdh.2016.16.2.507.

Henny Nuraeny, Trafficking of Migrant Workers in Indonesia: A Legal Enforcement and Economic
Perspective of Prevention and Protection Effort, European Research Studies Journal, volume XX, Issue 4B, 2017.

Manneke Budiman, "Jatidiri Budaya Dalam Masyarakat Multikultural", Makalah Seminar Pendidikan Multikultural dan Revitalisasi Hukum Adat dalam Perspektif Budaya, Departemen Kebudayaan dan Pariwisata, Bogor 18-20 Desember 2003.

Moh. Mahfud MD, "Keniscayaan Reformasi Hukum: Upaya Menjaga Jati Diri Dan Martabat Bangsa", Makalah dalam Konvensi Kampus VI dan Temu Tahunan XII Forum Rektor Indonesia (FRI) di Universitas Tanjungpura Pontianak, 9 Januari 2010.

Supriyanta, "Demokratisasi Dalam Penegakan Hukum", Wacana Hukum, Volume.VII, Edisi April 2008.

Zudan Arif Fakrulloh, SH., MH. Penegakan Hukum Sebagai Peluang Menciptakan Keadilan, Jurisprudence, Vol. 2, No. 1, Maret 2005.

Natsir, Muhammad, Demokrasi di Bawah Hukum, Media Dakwah, Jakarta: 1987.

Tanti Kirana Utami, The Position of Filling Pratama High Leadership in Cianjur Regency Under Good Governance Consept. Jurnal Dinamika Hukum, volume 17 No. 02 Mei 2017, FH-UNSOED, 2017. 